\title{
History of the Psychonomic Society IV: The development of the Psychonomic Society
}

\author{
DONALD A. DEWSBURY \\ University of Florida, Gainesville, Florida
}

\begin{abstract}
Although there have been many changes in the Psychonomic Society since its founding in 1959, its basic characteristics as a trim organization focused on the conduct of annual scientific meetings and a publication program for scientific research remain unchanged. Because full membership is limited to those who have published appreciable original scientific research beyond the $\mathrm{PhD}$, other means of quality control often have appeared unnecessary. Run by a Governing Board, which elects its own Chair, and a Secretary-Treasurer, the Psychonomic Society has avoided proliferation of administrative structure. Society leaders have worked to maintain a balance between responsible involvement with other organizations and a degree of independence that has enabled the Society to maintain its fundamental simplicity.
\end{abstract}

This is the fourth part of a four-part history of the Psychonomic Society (see Dewsbury, 1996, 1997; Dewsbury \& Bolles, 1995). The first three articles dealt with the founding, publications, and meetings of the Psychonomic Society. Although the publications and meetings constitute the Society's primary functions, it has many other diverse aspects; these are covered in the present article.

\section{THE NAME}

The story of the naming of the Psychonomic Society is summarized in Dewsbury and Bolles (1995). In brief, the selection represented something of a compromise intended to differentiate the brand of scientific study of behavior that was to be the purview of the new Society from psychology as it had come to be practiced in the American Psychological Association (APA).

The term has always caused some confusion and there have been some who have been unhappy with it. In a humorous section of the agenda for the 1965 meeting, Secretary-Treasurer William S. Verplanck asked "What are we?" and wondered whether we are psychonomists, psychonomers, psychgnomes, or psychonomes.

The closest that the Society has come to changing its name was in 1980, when, after discussing the matter at the 1979 Governing Board meeting, and at the instigation of Endel Tulving, the Governing Board established a three-person committee, chaired by Tulving along with Eliot Hearst and Robert Rescorla, to consider changing the Psychonomic Society's name. Tulving felt that the name conveyed little to those outside of the Society and that a name that would be meaningful to a larger audience would be useful. Although several alternatives were pro-

I thank Betty Capaldi, William Estes, Judith Goggin, Gregory A. Kimble, and Michael Rashotte for commenting on an earlier draft of this article. Correspondence should be addressed to D. A. Dewsbury, Department of Psychology, University of Florida, Gainesville, FL 32611 2065 (e-mail: dewsbury@psych.ufl.edu). posed, it is interesting that the name Tulving preferred in 1980 was the "American Psychological Society"- later to become the name of yet another organization. The next year, the committee recommended that the matter be put to a vote of the membership at the annual meeting in 1982. The matter died the following year when the committee "recommended no change given lack of interest in a new name and several letters against change" (GB minutes, November 1982). ${ }^{1}$ The committee was dismissed. The name seems destined for continued use.

\section{MEMBERSHIP}

A key aspect of any organization is the eligibility for membership.

\section{Full Membership}

From the very founding of the Psychonomic Society, a key principle was that only experimental psychologists with a demonstrated track record of publication of research beyond the dissertation would be eligible for membership (see Dewsbury \& Bolles, 1995). The founders were aware that most recipients of the $\mathrm{PhD}$ in psychology published no further research, and they wanted the Psychonomic Society to be an organization of active researchers. Furthermore, the founders were concerned about quality control at their meetings. They chose to be selective regarding membership in part because they did not wish to referee papers submitted for the annual meeting. They chose instead to allow all members, once accepted after scrutiny, to present papers. According to the founding bylaws, "a person must hold the Ph.D. degree or equivalent, and must have published significant research other than the doctoral dissertation" (Dewsbury \& Bolles, 1995, p. 229).

\section{Quality Control}

This policy necessitated great concern with the quality control that was effected in the screening of applicants for membership in the Society. The bylaws placed respon- 
sibility for voting in new members with the Governing Board. The responsibility for initial screening was placed, in turn, with a Membership Committee, consisting of three members of the Governing Board. Initially, prospective members were to send their names, addresses, names of institutions granting degrees, current position, current area of research, and a set of reprints or manuscripts in press of which the nominee was an author or a co-author (GB minutes, March \& April, 1960). Later, in 1960, the requirement of reprints was dropped, and application forms were printed.

The importance of quality control to the Board is apparent in the frequency with which they fine tuned the requirements and procedures. In their effort to maintain quality control, the Board was concerned that prospective members be senior authors, and they noted that "series of joint publications, and review articles are discounted" (GB minutes, September 1961). At that 1961 meeting, the committee recommended 28 applicants but recommended against 12 others ( $70 \%$ accepted), giving their reasons for each (GB minutes, September 1961). This was no rubber stamp committee. Such numbers were fairly typical; in 1982, for example, the Committee recommended 52 of 80 applicants ( $65 \%$ ); in 1985, just 44 of 86. More recently, the percentage of acceptance has been higher. By 1992 and 1995, for example, the committee approved 80 of $88(91 \%)$ and 62 of 67 nominations (92\%), respectively. This shift may have been due, in part, to a clearer statement of requirements for membership and increased self-selection. In 1976, the Board members decided that they wanted to see the entire publication record of applicants - not just a three-publication list as before.

In 1982 the membership requirements were made more explicit:

A successful candidate must be involved in scientific research in psychology or allied sciences and have published independently initiated research in refereed journals after obtaining the doctorate. Typically a successful candidate will be at least $2-3$ years post-Ph.D. and have four significant research publications based upon research after the date of the Ph.D.

(GB minutes, November 1982, p. 2)

A slightly revised statement of this policy was canonized on new application forms in 1985. Candidates had to sign a statement that they fulfilled the criteria.

Not all agree that the membership requirements that were appropriate in the 1960 s are still appropriate in the 1990s. Roediger (1992) editorialized that membership should be open to recent PhDs in order to make the activities more accessible to them and to expand the journal subscription base. There was no great enthusiasm for this change, and no revisions were made (Hasher, 1993).

\section{Life Membership}

In 1984, a new policy was adopted, granting Life Membership to any member who had belonged to the society for the previous 5 years and was of age 65 or older. These Life Members pay no dues and have no journal credit.
The Life Memberships were initially treated as not being a new membership category in need of a change of bylaws, but the change was made in 1986 .

\section{Associate Membership}

There was some concern about the need for limited participation by $\mathrm{PhD}$ psychologists who lacked the credentials to become full members of the Psychonomic Society. In 1974, the Governing Board asked the Membership Committee to conduct a study of a special category for individuals who were not yet ready for full membership. The category of Psychonomic Associates was established the next year. These were to be individuals with a $\mathrm{PhD}$ in psychology or related fields who were sponsored by Members. They receive notices of the annual meetings, a schedule of journal subscriptions, the Directory and the meeting program at cost, and other mailings, though they have no vote and make no dues payment. The initial fee was set at \$3. In 1977, a policy was formalized that Associates were not permitted to publish by themselves in the Bulletin of the Psychonomic Society, which was nonrefereed according to the same principles that guided the nonrefereeing process for paper presentation at meetings.

In 1980, it was determined that the Associate category was in violation of the bylaws, which stated that there could be but one class of membership. A new bylaw was passed to incorporate the Associate status. In addition, a 5 -year limit was placed on the time that individuals could remain in the Associate category. The 5-year limit was reaffirmed in 1984, but dropped in 1985 in an effort to encourage Associate membership.

\section{Charter Members}

Charter membership was granted to those initially nominated by the Governing Board according to a rather complex procedure (see Dewsbury \& Bolles, 1995). As of the first meeting in 1960, there were 736 charter members. Consistent with other aspects of the Society, there are few, if any, differentiations between charter members and those who joined later. Reference to charter membership was deleted from the bylaws early in the Society's history.

\section{Fellows?}

A fact indicative of the character of the Psychonomic Society is that the possibility of electing an elite class of fellows appears never to have been seriously considered. Article II, Section 1 of the original bylaws indicates that "the society shall have one class of membership" (Dewsbury \& Bolles, 1995, p. 229). Although this was later modified somewhat, from the beginning the Society has been an organization of peers.

\section{Students}

Although students have been welcome to attend meetings and to appear as co-authors on papers, they have never been eligible for membership. It is perhaps a bit ironic that, in 1993, the Governing Board, which had con- 
sistently opposed any increased student involvement, considered ways in which to increase journal subscriptions by students.

\section{Growth}

As of the first meeting in 1960 , there were 736 charter members. The membership had grown to 1,054 by 1964 and 1,869 by 1972 . Membership then hovered between 1,750 and 2,100 for many years. Representative totals of regular members plus life members are 1,752 in $1978 ; 1,725$ in $1983 ; 1,961$ in $1987 ; 2,029$ in 1987 ; and 2,025 in 1994 .

The number of Associates grew gradually from the inception of the category in 1975, with a boost in Associate memberships following the removal of the 5-year cap on Associate Status in 1985, the introduction of poster sessions, and a generally more accommodating environment for Associates. Representative numbers are 46 in $1978 ; 122$ in $1982 ; 222$ in $1984 ; 425$ in 1989 ; and 481 in 1994.

The number of Life Members, generally included within the category of "members," has risen slowly, with the following representative numbers: 83 in 1978; 109 in 1983; 104 in 1987; and 152 in 1994. With the much publicized aging of America in general and of academia in particular, one can expect that this figure will grow, just as in other organizations.

\section{Geographical Distribution}

According to a 1986 survey, $32.8 \%$ of the members lived in the Northeast, $15 \%$ in the Southeast, $24 \%$ in the Midwest, and $16.5 \%$ in the West; $11.7 \%$ were foreign.

\section{On Losing Blocks of Members}

As with all such societies, the Psychonomic Society has evolved and the interests of its members have changed over time. Periodically, the loss of particular groups has been noted and discussed, though not much could be done to change trends. Social psychology was long a problematic area in the Society, and some social psychologists, such as Anthony Greenwald and Martin Kaplan, made periodic efforts to secure a firmer position for the field in the Society. The problem was discussed by the Governing Board in 1986, but little action ensued. This was also the case with the loss of neuroscientists, discussed in 1984 and on other occasions.

\section{DUES}

All organizations require funds if they are to conduct essential business. As with most organizations, the Psychonomic Society has relied heavily on members' dues. The Society is somewhat unusual, however, in resisting the temptation to develop a large administrative hierarchy and thus has kept dues relatively low. According to the bylaws adopted with the founding of the Society, dues were set at $\$ 2$. They could be changed by a vote at a Business meeting on recommendation from the Governing Board of the Society (see Dewsbury \& Bolles, 1995). It may be an interesting bit of trivia that a special motion was passed in 1962 granting Professor Robert S. Woodworth an exemption from the payment of dues. As of 1973, the dues were $\$ 3$. The dues were raised to $\$ 5$ in 1975 .

When the journal publishing program faced a financial crisis following the death of publisher and financial benefactor Clifford T. Morgan in 1976, it became necessary to increase the number of member subscriptions to the Society journals (see Dewsbury, 1996). At its November 1976 meeting, the Governing Board voted to add a journal credit to the dues. Basic dues would remain at $\$ 5$. However, members would have to pay a minimum of $\$ 25, \$ 20$ of which would be applied to a journal subscription. In addition, a one-time-only assessment of $\$ 10$ was imposed on all members. These actions led to a marked increase in the number of members who either failed to pay dues or formally resigned (GB minutes, November 1977). Numerous members tried to retain membership by sending the $\$ 5$ dues without adding the journal credit charge; their memberships were not accepted. If members paid the full amount but did not use all of their journal credits, the difference was treated as a gift to the Society. The journal credit policy was extended to Associates in 1989 and was raised to $\$ 25$ in 1991 .

In 1981 the dues were raised to $\$ 10$ per year; dues for Associates would rise in synchrony. That same year a $\$ 5$ late fee was levied for any members not renewing their memberships on time.

In 1982, and at other times, the Board adopted a hard line approach toward those who did not pay dues. They "reaffirmed that there is no special inactive status, nor hardship status, nor foreign member status" (GB minutes, November 1982 , p. 3). However, as noted above, Life Memberships were introduced in 1983, thus creating a dues-exempt status.

\section{THE GOVERNING BOARD, OFFICERS, AND ELECTIONS}

Critical to understanding the governance of the Psychonomic Society is an understanding of the degree to which it was designed to avoid the sprawling hierarchy of the APA. The Psychonomic scientists wanted a streamlined and effective structure capable of organizing meetings and publications and not involved in the complex web of activities characteristic of the older organization. The initial bylaws placed responsibility for running the Society in a 12-person Governing Board, with each member serving a staggered, 6-year term, plus an appointed SecretaryTreasurer. Except for certain charter members, the members of the Board could not succeed themselves. The Board would elect its own Chairman, who would serve for 1 year, by a secret ballot. The Chairmanship was conceived as an administrative, as opposed to an honorary, office. The Secretary-Treasurer, appointed by the Board, 
could serve up to two consecutive 3 -year terms. There is an annual business meeting of the members, at which the Chair of the Governing Board presides.

Clifford T. Morgan was the first Chairman, and William S. Verplanck was the first Secretary-Treasurer. A complete list of members and chairs of the Governing Board is presented in Table 1. A list of SecretaryTreasurers appears in Table 2.

Members of the Governing Board are elected by the membership. Each year, the Secretary-Treasurer is to canvas the membership for nominations; the names of the six with the most nominations appear on the ballot. Each member can then vote for two nominees. In the event of the resignation, recall, or death of a Board member, there will be nine names on the ballot, each member can vote for three, and the individual finishing third fills the va- cant position with the right to succeed him- or herself. This occurred in 1979 upon the death of William Battig.

The precise means of electing Chairmen were spelled out in detail in 1961. The outgoing Chairman, serving as an election Committee, was to obtain a rank ordering of the eligible Board members from each Board member, with these members permitted to strike their names from the ballot if they did not wish to serve. This procedure was altered in 1982, when it was decided that the election would occur via a mail ballot among the four most senior members of the Board, with a runoff at the annual Board meeting in the event that one failed to secure a majority of the votes.

Because of the amount of clerical work and correspondence in the office of the Secretary-Treasurer, the Society has long provided some support. In 1982, the hiring

Table 1

Members of the Governing Board of the Psychonomic Society From Its Founding Until 1995

\begin{tabular}{|c|c|}
\hline Brogden, Wilfred, 1960 (1962) & Bourne, Lyle E., Jr., 1976 (1981) \\
\hline Estes, William K., 1960 & Kendler, Tracy S., 1976 \\
\hline Geldard, Frank A., 1960 & Hearst, Eliot S., 1977 \\
\hline Graham, Clarence, 1960 & Sternberg, Saul, 1977 (1982) \\
\hline Humphreys, Lloyd G., 1960 (1963) & Mandler, George, 1978 (1983) \\
\hline Morgan, Clifford T., $1960(1960)$ & Spence, Janet T., 1978 \\
\hline Neff, W. Dewey, 1960 (1961) & D'Amato, Michael R., 1979 \\
\hline Spence, Kenneth W., 1960 & Kintsch, Walter, 1979 (1984) \\
\hline Stevens, S. Smith, 1960 & Craik, Fergus I. M., 1980 (1985) \\
\hline Underwood, Benton J., 1960 & Rescorla, Robert A., 1980 \\
\hline Grant, David A., 1960 (1964) & Crowder, Robert G., 1981 \\
\hline Lindsley, Donald B., 1960 & Gormezano, Isidore, 1981 \\
\hline Geldard, Frank A., 1961 (1965) & Blough, Donald, 1982 (1987) \\
\hline Graham, Clarence, 1961 & Mandler, Jean M., 1982 (1986) \\
\hline Brown, Judson S., 1962 (1967) & Overmier, J. Bruce, 1983 \\
\hline Harlow, Harry F., 1962 & Shiffrin, Richard M., 1983 (1988) \\
\hline Kendler, Howard H., 1963 (1968) & Bolles, Robert C., 1984 \\
\hline Neff, W. Dewey, 1963 & Jenkins, Herbert M., 1984 \\
\hline Kimble, Gregory A., 1964 & Spear, Norman E., 1985 \\
\hline Solomon, Richard L., 1964 (1966) & Treisman, Anne M., 1985 (1989) \\
\hline Cofer, Charles N., 1965 & Potter, Mary C., 1986 (1991) \\
\hline Garner, Wendell R., 1965 & Roediger, Henry L., III, 1986 (1990) \\
\hline McGill, William, 1966 (1969) & Healy, Alice F., 1987 \\
\hline Wickens, Delos D., 1966 (1971) & Smith, Edward E., 1987 (1992) \\
\hline Estes, William K., 1967 (1972) & Hulse, Stewart, 1988 (1993) \\
\hline Riggs, Lorin, 1967 & Medin, Douglas L., 1988 \\
\hline Melton, Arthur W., 1968 (1970) & Johnson, Marcia K., 1989 (1994) \\
\hline Verplanck, William S., 1968 & Ratcliff, Roger, 1989 \\
\hline Atkinson, Richard, 1969 (1973) & Hasher, Lynn, 1990 (1995) \\
\hline Brown, Judson S., 1969 & Loftus, Elizabeth, 1990 \\
\hline Hake, Harold W., 1970 & Cooper, Lynn A., 1991 \\
\hline Logan, Frank A., 1970 (1974) & Egeth, Howard, 1991 \\
\hline Bower, Gordon H., 1971 (1975) & Capaldi, Elizabeth D., 1992 \\
\hline Solomon, Richard L., 1971 & Johnson, Neal F., 1992 \\
\hline Grice, G. Robert, 1972 (1977) & Jacoby, Larry, 1993 \\
\hline Thompson, Richard F., 1972 (1976) & Klatzky, Roberta L., 1993 \\
\hline Amsel, Abram, 1973 (1978) & Domjan, Michael, 1994 \\
\hline Kimble, Gregory A., 1973 & Neely, James H., 1994 \\
\hline Jenkins, James J., 1974 (1979) & Bjork, Robert A., 1995 \\
\hline Posner, Michael I., 1974 & Zacks, Rose, 1995 \\
\hline Greeno, James, 1975 (1980) & Gernsbacher, Morton Ann, 1996 \\
\hline Tulving, Endel, 1975 & Rayner, Keith, 1996 \\
\hline
\end{tabular}

Note-Year of election to term follows each name. Founders were members at the beginning of the Society's history. Chairs of the Governing Board are shown with their year of service in parentheses. 
Table 2

Secretary-Treasurers of the Psychonomic Society From Its Founding Through 1997

Verplanck, William S., 1960-1965

Morgan, Clifford T., 1965-1970

Mote, Frederick A., 1971-1974

Spence, Janet T., 1975-1977

Voss, James S., 1978-1980

Overmier, J. Bruce, 1981-1983

Goggin, Judith P., 1984-1986

Rashotte, Michael, 1987-1989

Null, Cynthia H., 1990-1992

Martin, Randi C., 1993-1995

Mellgren, Roger L., 1996-

of a $1 / 5$ time clerk/typist was approved in lieu of an hourly hire. A stipend of $\$ 3,000$ for the Secretary-Treasurer was approved in 1983; this was later raised to $\$ 5,000$, and, in 1994 , to $\$ 8,000$. In addition, staff in the Publications Office have assumed some of the responsibilities, thus lightening the load of the Secretary-Treasurer somewhat.

\section{BYLAWS}

The document that defines the nature and procedures of the Psychonomic Society is the set of bylaws that was adopted on December 30,1959, and has undergone some modification since. These bylaws were reprinted in full by Dewsbury and Bolles (1995). Successive articles of these bylaws deal with the Name and Object of the Society, Membership, the Governing Board, Officers, Elections, Meetings, Publications, Dues, Recall, and Amendments.

Once Charter Membership was complete, on December 31,1961 , amendments could be proposed by the Governing Board, or by motion from the floor at the annual business meeting. Passage required a two-thirds vote of those voting in a mail ballot sent, along with a statement of the Board's recommendation, to the membership. The Article describing these procedures was later itself amended, the most important change being that amendments could be passed either by mail or by vote at the annual business meeting.

The fundamental bylaws adopted in 1959 remain in effect today. Various amendments that have been passed are discussed in context elsewhere in this series of articles. These have generally concerned matters of membership and dues. The addition of Associates and Life Members and the exemption of foreign members from Federationrelated assessments (see below) required bylaws amendments. Reference to charter memberships, which appears in the original bylaws, was later deleted by amendment.

Some housekeeping amendments were passed in 1962 in order to secure tax-exempt status for the new organization.

\section{COMMITTEES}

Consistent with the overall philosophy of the Society, the committee structure has been kept simple. The central authority is placed in the Governing Board. In the early years, the Board met twice a year: once at the annual meeting and often a second time in association with the meetings of the Society of Experimental Psychologists. Since 1964, there has generally been a single annual Board meeting.

In the first years, there were a Program Committee and an Arrangements Committee to plan the annual meeting. These duties later were performed by the SecretaryTreasurer, thus eliminating the need for these committees.

As noted above, the Membership Committee is composed of three Governing Board members and is charged with screening applicants for membership.

The most critical committee is the Publications Committee, which began as an ad hoc committee in 1961 but was later established as a permanent committee in 1974 (see Dewsbury, 1996).

In the 1980 s, animal activism led many societies to establish committees on animal research. The Governing Board considered establishing such a committee but, consistent with many of its other principles, bucked the tide and decided against establishing such a committee. The structure was to be kept simple.

\section{BUDGETS}

As would be expected, the budgets grew and became more complex with time. In 1961, for example, the budget showed income from dues, program sales, registration fees, and loans totaling $\$ 2,122.86$ and expenditures for Founding costs, the 1960 meeting, and mailing, and clerical expenses of $\$ 2,073.43$ (Psychonomic Society Newsletter, 1961). By contrast, the interim financial statement for 1991 showed an income of over $\$ 58,000$, with disbursements of over $\$ 45,000$.

The Publications Office has always been semiindependent of the rest of the Society, so the preceding figures exclude publication-related income and disbursements. In 1977, to take one example, the assets, liabilities, income, and expenses of the Psychonomic Society were each under $\$ 10,000$; the Publications Office reported assets of nearly $\$ 180,000$.

The cash balance as of January 1, 1982, was under $\$ 6,000$. By 1993 , Secretary-Treasurer Randi Martin could report that the Society had assets in excess of $\$ 100,000$. A 1981 dues increase and restructuring of reserves provided some of the impetus for this growth.

Indeed, the financial status of the Psychonomic Society became sufficiently strong so that it could help the Publications Office in a time of need. In March 1987, the Governing Board authorized the purchase of the building at 1710 Fortview Road in Austin, Texas, for the Publications Office (see Dewsbury, 1996). A \$200,000 bank mortgage was obtained. In 1988, the Governing Board authorized an interest-free loan of of $\$ 50,000$ to the Publications Office to help pay down the mortgage (GB minutes, 1988). In 1990, an additional $\$ 10,000$ was added to the loan. The loan was repaid at the rate of $\$ 500$ per month for several years, but in 1992 the Governing Board voted to forgive the balance of the loan (GB minutes, 1992) 


\section{EXTERNAL AFFAIRS}

During the time of the Psychonomic Society's own history, other scientific and academic organizations have proliferated. A fundamental principle in the initial conceptualization of the Psychonomic Society was that it should be independent of all other organizations. Thus, at the very first meeting of the Organizing Committee, it was decided that the Society would be independent of the APA and that "no affiliation of any sort be considered" (GB minutes, December 1959). The Board would struggle with the conflict between isolationism and involvement on various occasions. Although the Board has been reluctant to enter into associations with other organizations, it has made some exceptions.

As early as 1960 , before the first scientific meeting, the Board discussed possible associations with the American Association for the Advancement of Science, the National Research Council, the National Science Foundation, and the American Institute of Biological Sciences (AIBS). No action was taken. A possible affiliation with the AIBS was rejected at four different meetings. In 1961, Neal Miller wrote to the Board regarding a new international society; the Board remained independent and declined participation. In the early years, the Board also rejected moves to establish Australian and European branches of the Psychonomic Society. The primary concern was the difficulty of retaining strict and comparable standards for membership. In more recent years, the Board has made efforts to recruit foreign members, but only into the one Psychonomic Society.

A joint meeting was held with the Psychometric Society in 1964, but no lasting relationship was established.

In 1982, a motion that the Society join the Consortium of Social Science Organizations and pay the dues of over $\$ 1,700$ died without a second.

In 1983, possible affiliation with the National Coalition for Science and Technology was discussed and rejected. In 1986, the Board declined an invitation to become a member of the Commission on Professionals in Science and Technology.

\section{Association of Applied Psychology}

At some point, probably in the 1970 s, the Board did approve affiliation with the Association of Applied Psychology (AAP). A $\$ 100$ membership renewal appears in the 1980 budget, and motions to continue membership were passed in 1979 and 1980. The amount was increased to $\$ 250$ in 1981 and $\$ 500$ by 1984 . The affiliation was dropped in 1985, when the benefits to the Psychonomic Society did not seem commensurate with the costs of affiliation.

\section{Federation of Behavioral, Psychological and Cognitive Sciences}

One problem for the Board was that, although the members were determined to remain free of political and lob- bying activity, the activities of their members were closely tied to fluctuations in federal funding. How could the Society remain both independent and involved in what was happening around it? The solution was the Federation of Behavioral, Psychological and Cognitive Sciences. The idea for the Federation emerged from the Psychonomic Society. The problems of representation were discussed at the 1978 Governing Board meeting, but no action was taken at that time (Greeno \& Bourne, 1981). Under Abram Amsel's leadership, the Governing Board reasoned that numerous scientific societies similar to the Psychonomic Society could benefit from better representation in Washington that would be different from the practiceoriented efforts that dominated the APA's efforts at that time (Amsel, 1995). By the next year, there had been much discussion of the idea among representatives of different organizations. A committee established to study questions of research funding procedures and chaired by James Greeno, and including George Mandler and James Jenkins, reported in 1979 that the Society should participate in sponsoring a meeting of representatives of various societies whose membership was involved in psychological research. The meeting was held in Chicago in June 1980. The next year, the Board passed a motion that the Psychonomic Society should join the Federation as a charter member and contribute $\$ 750$ as charter dues, and that a $\$ 3$ dues increase to members be assessed to help fund the Federation. Greeno became the president of the Federation in 1982. In that year, Federation membership was continued, with the dues assessment raised to $\$ 5$.

The Chairman appointed two representatives to the Federation; in 1981, George Mandler and R. Duncan Luce were appointed for the next year. In addition, it nominated individuals for positions within the Federation. Each year, the Governing Board heard a report from its representatives or from an officer of the Federation, which held, among other activities, science and public policy seminars, formed a committee on grant procedures and policies as well as animal research committees, held a conference on supercomputers, and organized testimony for various Federal agencies. In 1985, the Board approved another $\$ 2$ increase in dues to go to the Federation. A bylaw exempting foreign members from the Federation fees was passed in 1986. By 1989, the Federation dues had risen to $\$ 7-10$ per member.

The Federation came to be housed in the APA building in Washington, and it received various kinds of support from the APA. It is somewhat ironic that an organization originally designed to provide an alternative to APA-based lobbying should become housed within the APA space.

\section{International Union of Psychological Sciences}

By 1985, the Psychonomic Society had affiliated with the International Union of Psychological Sciences (IUPS). George Mandler was ratified as the Psychonomic Society's Union representative in 1985; Lynn Cooper, the latest representative, was appointed in 1996. This organi- 
zation's activities include the conduct of International Congresses of Psychology and the formation or maintenance of committees dealing with such issues as developmental psychology, the psychological study of peace, the psychology of global change, and human-computer interactions (GB minutes, 1991).

In the 1990 s, the Society made contributions of $\$ 1,200$ 1,500 to a foreign journal fund run through the IUPS.

\section{National Association for Biomedical Research}

As noted below, the Board joined in an amicus curiae brief filed by the National Association for Biomedical Research and other organizations to protect research animals formerly used by Edward Taub. This was part of a landmark effort by animal activists to restrict the use of animals in experiments in physiological psychology.

\section{Society for Computers in Psychology}

Another group that has been close to the Psychonomic Society has been the Society for Computers in Psychology. The participation of that Society at Psychonomic Society meetings is discussed by Dewsbury (1997).

\section{American Psychological Society}

In the 1980s, a group of academic and scientific psychologists moved to separate themselves from the APA by forming first the Assembly for Scientific and Applied Psychology (ASAP) and then the American Psychological Society (APS), which emerged from it. Many members of the Psychonomic Society were affected by these developments. In 1987, the Board authorized publication of an announcement of the formation of the ASAP in each of the Society's journals. The Board also asked Chairman Richard Shiffrin to write a letter to the APA supporting the Assembly. With the APS formed, the issue was revisited in 1988. By an eight to two vote, the Board decided to send a $\$ 250$ contribution to the APS as a gesture of goodwill but decided not to become an institutional affiliate of the new group. Further, the group agreed to send a representative, J. Bruce Overmier, to a January 1989 meeting in Norman, Oklahoma, to discuss the organizational structure of the APS. Overmier reported on this first "summit" meeting the next year and was joined by Alan Kraut, Executive Director of the APS. The Board voted to continue making a $\$ 250$ contribution to the APS but not to become an affiliate. Overmier and Stewart Hulse would attend the second summit meeting.

\section{Council of Scientific Society Presidents}

In 1989, the Board approved a 1-year trial membership in the Council of Scientific Society Presidents at a cost of $\$ 0.07$ per member.

\section{POTPOURRI}

There were many other issues that arose as the Governing Board administered the affairs of the Society in the context of a world growing ever more complex.

\section{Newsletters and Membership Directories}

During the first 5 years of its existence, the Society published a newsletter. These newsletters, published between 1960 and 1964, included summaries of the scientific meeting, minutes of the Business Meeting, miscellaneous information about the Society, and a roster of members.

After a long period without newsletters, in 1991 the Governing Board decided to resume the practice. Again, the Newsletters carried basic news of the organization and its activities. The format was greatly improved over that of the earlier versions.

The first full Membership Directory, with addresses, was published in 1967. Subsequent directories have been issued at varying intervals and have included more information, as telephone numbers and electronic mail addresses were added. At present, a new directory is printed every 2 years.

\section{Mailing Labels}

Organizations such as the Psychonomic Society receive many requests for mailing labels from both commercial and nonprofit organizations. In 1964, the Board decided to provide labels for scholarly groups but not for commercial interests. The policy was affirmed in 1977, and in 1980 a motion to sell labels to Harvard University Press was defeated. The policy was changed in 1982 , when it was decided to sell mailing lists to scientific/nonprofit organizations at cost and to profit-making organizations at cost plus $\$ 100$, provided that the latter would also purchase advertising space in the journals and that the Secretary-Treasurer approved the sale.

\section{Liability Insurance}

In 1986 , concern was raised about the need for liability insurance for the Board. It was determined that the policy taken out by the Publications Office also covered the Board. The next year, the Board decided to split costs with the Publications Office, with the Board paying one third of the cost.

\section{Remaining Nonpolitical}

The Board has maintained its effort to remain as nonpolitical as possible, although many exceptions can be noted. In 1984, it declined to solicit funds for the defense of Edward Taub against animal cruelty charges, although Saul Sternberg, the Governing Board Chair, did write a letter expressing concern to James B. Wyngarden of the National Institutes of Health and issued a statement in support of Taub. Later, however, the Society did join with the National Association for Biomedical Research in an amicus curiae brief to protect the Taub animals, contributing $\$ 250$ toward that endeavor.

In 1988, the Governing Board voted against establishing a committee to make public statements on the Society's behalf.

\section{Certification}

One fundamental reason for the founding of the Society was dissatisfaction with the increasingly restrictive 
activities of the APA. An important issue was the extent to which the APA was perceived as working to dictate policies for graduate education to faculties by establishing standards and requirements that seemed arbitrary to many experimental psychologists. Often the professional interests within the APA worked with governmental agencies at various levels to affect certification and licensing mechanisms. The Governing Board grappled with the issue at several early meetings. There was much correspondence and discussion of the impact of certification laws in a variety of locations, including New York State, on experimental psychology. The following resolution was adopted at the 1962 business meeting:

\begin{abstract}
Be it resolved:
The Psychonomic Society has for its avowed purpose the promotion of the communication of scientific research in psychology and allied sciences.

Therefore, it must oppose any provision in certification laws or administrative practices that interfere with the freedom of Departments of Psychology to determine the program of graduate education most appropriate for the education of scientists in the area of psychology.
\end{abstract}

$$
\text { (Verplanck, 1962, p. 11) }
$$

It is interesting that in their effort to keep political activity to a minimum, the Society had to pass a resolution with political intent. In response, the APA established a Special Committee on Registration of Graduate Programs in Psychology. Its report, presented at the 1963 business meeting of the Psychonomic Society, indicated that, as of that time, the APA supported accreditation of programs but opposed detailed specifications of curriculum.

\section{Gender Issues}

At the 1972 business meeting, Harriet Amster announced that a group of woman members of the Society had met to discuss the issue of women's participation in the Society and to further the election of women to the Governing Board. They formed a group called Psychonomic Women (Anonymous, 1972). Nancy Anderson was chosen as the group's leader.

Although there has been a balanced gender ratio on the Board in recent years, it was not until 1976 that the first woman, Tracy S. Kendler, was elected. The first three women elected were outstanding scientists on their own and also married to former members of the Board.

\section{Minority Issues}

At the 1983 meeting, a group met to discuss minority recruitment to the Society (Reyna, 1984). The group was not an official committee of the Psychonomic Society, but met informally for several years under the leadership of Valerie Reyna and Slater Newman. It functioned as a faculty network of experimental and applied psychologists working in two areas: working to sensitize members and others to issues involved in the training and hiring of minorities and women and actually connecting job seekers with jobs.

\section{Letters of Commendation}

In an unusual move, the Governing Board passed a resolution honoring Henry Odbert as he retired from his position as Program Director of the Psychobiology Program at the National Science Foundation in 1973. However, in 1986 a policy was adopted against issuing commendation letters for individual Festschrifts.

\section{Awards}

In 1993, a committee was established to consider whether awards for scientific achievement should be made by the Society. James Pomerantz, Elizabeth Loftus, Neal Johnson, and Marcia Johnson were appointed to serve. The Committee decided that the difficulties of administering an awards program outweighed the benefits thereof. In 1995 a new committee, comprising Richard Shiffrin, Chair, Irving Biederman, James Pomerantz, Roberta Klatzky, and J. Bruce Overmier, with Howard Egeth ex-officio, was formed to revisit the issue.

\section{Web Site}

Since December 1996 a World-Wide Web site devoted to Psychonomic Society Publications has been on line. The address is http://www.sig.net/ psysoc/home.htm. Articles dealing with the Psychonomic Society's history are linked to the home page.

\section{HISTORIOGRAPHY}

The Psychonomic Society began to deal with matters of its history earlier than numerous other organizations. In 1977, John A. Popplestone of the Archives for the History of American Psychology at the University of Akron asked to be appointed the Society's archivist. The archival collection that was subsequently created provides a rich source for anyone interested in the history of the Psychonomic Society.

It should be noted, however, that these materials are incomplete. For example, during 1966-1969, when he was Secretary-Treasurer, Clifford T. Morgan apparently prepared no minutes of Governing Board meetings. There are numerous other times or events for which essential information appears unavailable.

The 20th anniversary of the Psychonomic Society coincided with what is often regarded as the 100th anniversary of experimental psychology, marked by the founding of Wilhelm Wundt's laboratory at the University of Leipzig in 1879. The events were celebrated through sponsorship of an edited volume under the editorship of Eliot Hearst (1979).

In 1984 , the Society celebrated its 25 th anniversary with an Anniversary session at the annual scientific meeting in San Antonio. Members of the founding group and the early Governing Boards discussed the founding of the Society, the initial objectives, and the results of their experience (see Dewsbury, 1997).

In 1987, Secretary-Treasurer Michael Rashotte proposed that the Society update its history. The matter was 
deferred. Henry L. Roediger III took up the matter and arranged the appointment of Robert C. Bolles as the first Historian of the Psychonomic Society in 1991. Bolles died on April 8, 1994, after beginning the project of writing a history of the Psychonomic Society. Donald A. Dewsbury was appointed to succeed Bolles in 1994. The present article completes the basic history as of the time of this writing.

\section{REFERENCES}

AMseL, A. (1995, March 7). [Taped interview with Donald A. Dewsbury. Austin, TX].

ANONYMOUS (1972). Psychonomic women: Statement of business meeting St. Louis, 1972 (Psychonomic Society Archives, Box 488.1). Akron, $\mathrm{OH}$ : University of Akron, Archives of the History of American Psychology.

DewsBury, D. A. (1996). History of the Psychonomic Society II: The journal publishing program. Psychonomic Bulletin \& Review, 3, 322338

Dewsbury, D. A. (1997). History of the Psychonomic Society III: The meetings of the Psychonomic Society. Psychonomic Bulletin \& Review, 4, 350-358.

Dewsbury, D. A., \& Bolles, R. C. (1995). The founding of the Psychonomic Society. Psychonomic Bulletin \& Review, 2, 216-233.

Greeno, J., \& Bourne, L. (1981). Proposal to continue affiliation with the Federation of Behavioral, Psychological, and Cognitive Sciences (Psychonomic Society Archives, Box 650). Akron, OH: University of Akron, Archives of the History of American Psychology.

HASHER, L. (1993, Spring). Membership committee. Newsletter of the Psychonomic Society, p. 3

HEARST, E. (ED.) (1979). The first century of experimental psychology. Hillsdale, NJ: Erlbaum.

ReYNA, V. F. (1984, June 26). [Untitled]. (Psychonomic Society Archives, Box 725). Akron, $\mathrm{OH}$ : University of Akron, Archives of the History of American Psychology.

RoEDIGER, H. L. III (1992, Fall). Viewpoint: Should the Psychonomic Society change its membership requirements? Newsletter of the Psychonomic Society, p. 7.

VerPLANCK, W. S. (1962). Third annual business meeting. Newsletter of the Psychonomic Society, pp. 7-11.

\section{NOTE}

1. References to the "GB Minutes" refer to the minutes of the meetings of the Governing Board. These are available either at the Archives of the History of American Psychology in Akron, $\mathrm{OH}$, or at the Psychonomic Society offices in Austin, TX.

(Manuscript received January 23, 1997; revision accepted for publication May 13, 1997.) 